\title{
Ultra fast-track trans-axillary mini-aortic valve replacement
}

\author{
Marco Di Eusanio ${ }^{1}$, Jacopo Alfonsi ${ }^{1}$, Paolo Berretta ${ }^{1}$, Hossein Zahedi ${ }^{2}$, Michele D. Pierri ${ }^{1}$, \\ Mariano Cefarelli ${ }^{1}$ \\ ${ }^{1}$ Cardiac Surgery Unit, Lancisi Cardiovascular Center, Polytechnic University of Marche, Ancona, Italy; ${ }^{2}$ Cardiac Anaesthesia and Intensive Care \\ Unit, Lancisi Cardiovascular Center, Ancona, Italy \\ Correspondence to: Mariano Cefarelli. Lancisi Cardiovascular Center, Polytechnic University of Marche, Via Conca 71, 60126, Ancona, Italy. \\ Email: mariano.cefarelli@gmail.com.
}

Submitted Mar 05, 2020. Accepted for publication Apr 28, 2020.

doi: 10.21037/acs-2020-surd-19

View this article at: http://dx.doi.org/10.21037/acs-2020-surd-19

\section{Introduction}

Despite minimally-invasive aortic valve replacement (MIAVR) having gained interest within the cardiac surgeons' community, patient requests for interventions associated with minimized trauma and faster recovery often remains unfulfilled (1). In our center, we believe that a MI-AVR program (2) may benefit from a multidisciplinary approach that combines reduced incisions with an increasing use of rapid deployment valves (RD), minimal invasive extracorporeal circulation system (MiECC) (3) and fast-track anesthetic (UFT) management. Our experience with the MI trans-axillary direct approach in mitral valve surgery (MVS) (4) led us to consider that the aortic valve could be nicely exposed from the same approach. As a result, we recently initiated the use of trans-axillary incisions for MI-AVR in selected patients. In this setting, RD valves may help with reducing technical complexity and operative times. The aim of this video is to share our approach in a step-by-step fashion.

\section{Clinical vignette}

The patient was an 80-year-old-male presenting with NYHA-III symptoms due to his severe aortic valve stenosis. Transthoracic echocardiogram showed a max/med transvalvular gradient of 99/66 $\mathrm{mmHg}$; where the left ventricular function was preserved. Coronary angiography ruled out any significant coronary disease. The EuroSCORE II was $1.6 \%$. A patient-informed consent form for treatment, data collection and analysis for scientific purposes were collected.

\section{Surgical technique}

On the operating table, the right posterior chest wall was elevated with a roll. After induction of anesthesia with fentanyl and propofol, a short-acting volatile agent (sevoflurane) was used to maintain anesthesia before and after extra-corporeal circulation (ECC). A transesophageal echocardiography (TEE) probe was placed and a thorough echocardiographic evaluation was performed. The groin vessels were exposed through a $2 \mathrm{~cm}$ longitudinal incision. After heparinization, with the Seldinger technique and TEE guidance, a 25-French venous cannula (Livanova, London, UK) was inserted with the tip well-placed in the superior vena cava. The femoral artery was cannulated with a 19-French arterial cannula (Biomedicus, Medtronic, Minneapolis). A $6 \mathrm{~cm}$ incision was performed on the right anterior axillary line. The $3 \mathrm{rd}$ intercostal space (ICS) was entered. A soft tissue retractor and an intercostal rib spreader provided additional exposure. The pericardium was opened over the aorta and extended down towards the inferior vena cava. After ECC institution, a minimallyinvasive clamp (Cygnet ${ }^{\circledR}$ Flexible Clamps, Vitalitec, USA) was applied across the distal ascending aorta, and warm blood cardioplegia was given through the aortic root A "hockey-stick" aortotomy crossing the sinotubular junction was performed and the aortic valve exposed. The aortic cusps were removed and the annulus decalcified. The aortic annulus was measured and a $23 \mathrm{~mm}$ Intuity Elite ${ }^{\mathrm{TM}} \mathrm{RD}$ valve was implanted in the usual fashion. The aortotomy was closed and before releasing the aortic clamp, two pacing wire electrodes were applied to the right ventricle. The left ventricle was de-aired and the aortic clamp released. Total ECC and cross-clamp times were 60 and 42 minutes, respectively. Once hemostasis was satisfactory, the ribs were approximated with two single non-absorbable stitches. A few minutes before surgery completion, the inhalational 
agent was stopped. Local anesthetic infiltration of suture and drain sites were used for immediate postoperative pain relief. Table extubation was performed once usual extubation criteria were fulfilled. After extubation, the patient was transferred to the intensive care unit where mobilization and respiratory therapy were started 3-4 hours after surgery. The morning after, the drains were removed and the patient was transferred to the ward.

\section{Comment}

In this video-article we sought to share our RD transaxillary MI-AVR program. At the Lancisi Cardiovascular Center, we currently use three surgical minimally-invasive approaches to expose and replace the aortic valve: the ministernotomy, the anterior right minithoracotomy, and the trans-axillary approach. The latter was introduced based on our growing experience with direct access trans-axillary mini-MVS and highlighted how valid the alignment with the aortic valve could be from a more lateral approach (4). In fact, compared to other available incisions for MIAVR, the trans-axillary is associated with the following advantages:

(I) The ICS is wider compared to more anterior positions with less need for rib spreading or cutting. Moreover, the right internal thoracic artery can always be preserved;

(II) A superior cosmetic result; in fact, this is the only surgical MI-AVR approach that results in invisible scars from an anterior view. The patient has to lift up the right arm to make the incision visible;

(III) A very favorable 90-degree alignment with the aortic valve and nice exposition of all three aortic sinuses.

As we do with other MI-AVR interventions (5), the transaxillary approach can be implemented with the use of RDvalves and UFT-anesthesia. In fact, the former is effective in minimizing: (I) complexity of valve implantation, (II) operative times, and (III) trans-valvular gradients; while the latter allows: (I) aggressive rehabilitation programs in the early hours, and (II) immediate patient-family contact with improved comfort and better perception and satisfaction of the received MI procedure. In our opinion, UFT RD transaxillary MI-AVR represents an interesting additional option for patients requiring AVR. We are well aware that we are in the early phase of our learning curve and that more solid data are necessary to confirm our initial encouraging hunch.

\section{Acknowledgments}

None.

\section{Footnote}

Conflicts of Interest: The authors have no conflicts of interest to declare.

Open Access Statement: This is an Open Access article distributed in accordance with the Creative Commons Attribution-NonCommercial-NoDerivs 4.0 International License (CC BY-NC-ND 4.0), which permits the noncommercial replication and distribution of the article with the strict proviso that no changes or edits are made and the original work is properly cited (including links to both the formal publication through the relevant DOI and the license). See: https://creativecommons.org/licenses/by-nc-nd/4.0/.

\section{References}

1. Beckmann A, Funkat AK, Lewandowski J, et al. German Heart Surgery Report 2016: The Annual Updated Registry of the German Society for Thoracic and Cardiovascular Surgery. Thorac Cardiovasc Surg 2017;65:505-18.

2. Di Eusanio M, Vessella W, Carozza R, et al. Ultra fasttrack minimally invasive aortic valve replacement: going beyond reduced incisions. Eur J Cardiothorac Surg 2018;53:ii14-18.

3. Berretta P, Cefarelli M, Montecchiani L, et al. Minimally invasive versus standard extracorporeal circulation system in minimally invasive aortic valve surgery: a propensity score-matched study. Eur J Cardiothorac Surg 2020;57:717-23.

4. Di Eusanio M, Berretta P, Alfonsi J, et al. Ultrafast-Track Mini Mitral Valve Repair: Direct Access Transaxillary Approach. October 2019. doi:10.25373/ctsnet.9899270.

5. Berretta P, Cefarelli $M$, Vessella $W$, et al. Ultra fast track surgery: a rapid deployment aortic valve replacement through a J-ministernotomy. J Vis Surg 2018;4:90.

Cite this article as: Di Eusanio M, Alfonsi J, Berretta P, Zahedi H, Pierri MD, Cefarelli M. Ultra fast-track transaxillary mini-aortic valve replacement. Ann Cardiothorac Surg 2020;9(5):427-428. doi: 10.21037/acs-2020-surd-19 